\title{
The Cause of Stunting Towards Toddler At Parit Public Health Center of Pasaman Barat, West Sumatera
}

\author{
Yulfira Media ${ }^{1}$, Nilda Elfemi ${ }^{2}$ \\ \{Fira.media@yahoo.com ${ }^{1}$,nildaelfemi@stkip-pgri-sumbar.ac.id ${ }^{2}$ \} \\ ${ }^{1}$ Research and Development Agency of West Sumatra Province, Padang, Indonesia \\ ${ }^{2}$ STKIP PGRI West Sumatera, Padang, Indonesia
}

\begin{abstract}
A relatively poor nutritional status and stunting of toddlers become also raising problems in the development of the health sector in West Sumatra. The purpose of this research was to find out some aspects causing stunting cases. This research was conducted in the area of Parit Public Health Center in Pasaman Barat Regency, West Sumatra Province, in 2018. The research design used a qualitative method where data collection techniques using observation and in-depth interviews 15 informants using interview guidelines. Data were analyzed through a qualitative approach. The results show that some aspects of the stunting problems are socio-cultural aspects, including parenting and feeding behavior, economic conditions and family environment, health care, and access to health services. Alternative suggestions include increasing public knowledge about stunting and stunting prevention efforts, implementing behavioral change interventions for stunting prevention towards environmental strengthening, and optimizing community empowerment.
\end{abstract}

Keywords: Stunting, Socio-Cultural, Economics, Environment, Health Access

\section{Introduction}

Toddler age is a group that is susceptible to malnutrition, where one of the cases is stunting. Stunting is a linear growth disorder caused by chronic nutrient intake or chronic infection malnutrition or even repeating as indicated by the height $\mathrm{z}$-score according to age (TB/U) less than -2 Elementary School [1].

The problem of stunting is a serious threat to Indonesian children today. Indonesia is among 47 countries of 122 countries, which have a stunting problem for Toddler and anemiaat WUS. Furthermore, based on the results of Basic Health Research (2013), for the national scale, the prevalence of stunting toddler in Indonesia is 37.2\% [2]. World Health Organization (WHO) sets a tolerance limit for stunting ranging $20 \%$ of the total number of a toddler in maximum.

The relatively poor nutritional status and stunting of toddlers become problems in the development of West Sumatra in the Health sector (RPJMD of West Sumatra Province 20162021)[3]. Based on 2013, Basic Health Research data, the prevalence of short and very short among toddlers in West Sumatra is $39.24 \%$, and this figure exceeds the national prevalence, which is $37.21 \%$ [2]. The problem of stunting among toddlers needs to be a concern in West Sumatra because the condition has been reaching $39.2 \%$. According to WHO, the prevalence 
criteria considered into severe are like the short prevalence is 30-39 percent and categorized into serious if the short prevalence is $\geq 40$ percent. Furthermore, from the description of nutritional status data for toddlers, 0-59 months in West Sumatra from the Nutritional Status Monitoring (PSG) started from 2015 to 2017, it shows that the percentage of short and very short toddler categories based on TB / U has increased in 2017 which is $30,6 \%$. In contrast, in 2015 , it was $27,6 \%$, and $25,5 \%$ in $2016 \%$ (Figure 1)[4].

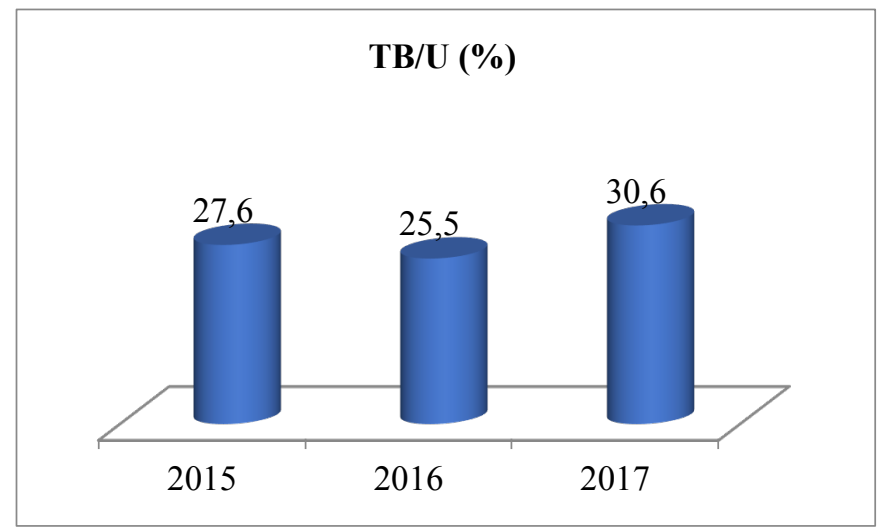

Fig 1. The description of nutritional status data for toddlers 0-59 months in West Sumatra (PSG 20152017)

Pasaman Barat Regency is one of the districts with a percentage of the toddler (0-59 months) categorized into short and very short criteria ranging from $32.1 \%$ in 2017 . The data are even higher than the West Sumatra average (30.9) and more than the national average (29.6\%). Pasaman Barat Regency is one of the two districts in West Sumatra Province, becoming the priority area for stunting handling in 2018 [4]. According to the results of the mass weighing in 2017, the nutritional status of toddlers in Pasaman Barat Regency based on TB / U for the very short category is 1457 , and for the short category is 4317 . In addition, Parit Public Health Center is one of Public Health Centers with the highest case of stunting toddlers in Pasaman Barat Regency i.e., 339 cases in 2017 [5].

The stunting is caused by chronic malnutrition caused by poverty and inappropriate parenting resulting in cognitive abilities that will not develop optimally, for example: easily hurting and low competitiveness. So it will turn back into poverty. The stunting in a toddler is an impact of several factors mostly associated with poverty, including nutrition, health, sanitation, and environment. There are five main factors that cause stunting, namely poverty, social and culture, increased exposure to infectious diseases, food insecurity, and community access to health services [1].

Lepine stated (in Permampu Consortium, 2017)[6] that women are the primary parenting for children. The quality of parenting will largely determine the nutritional status of children, apart from the availability of food and the health environment. Furthermore, women's autonomy also has an indirect impact on children's health because it affects the nutritional status and condition of women, which is in turn, and it will influence the nutritional quality of children during pregnancy and health and nutrition after giving birth. Then, it is necessary to 
find out the aspects causing the incidence of stunting in toddlers in the Parit Public Health Center, Pasaman Barat Regency. The purpose of this research is to find out the aspects causing the incidence of stunting in toddlers, especially from the socio-cultural aspects, economic and environmental conditions, health services, and access to health services.

\section{Method}

The study was conducted in Parit Public Health Center in Pasaman Barat Regency, West Sumatra, in 2018. Selecting the location was based on the consideration where Parit Public Health Center was one of the highest numbers of cases in Pasaman Barat Regency, which was 339 cases in 2017 [5]. Data collection was carried out through an in-depth interview with 15 informants using interview guidelines. The research informants were stunting case families, Head of Public Health department, several Section Heads in Health Department of Pasaman Barat Regency, Nutrition program holders, Heads of Public Health Center, and the village midwife. Besides in-depth interviews, observations were also conducted, especially on the sanitary conditions and stunting family environment. Data were analyzed using qualitative rules with a content analysis method, which were carried out through several stages. The first steps were to transcribing the data and sorting data by groups of questions. Furthermore, the data were presented in a matrix of interviews, along with the explanation.

\section{Result}

The results of interviews with stunting families show that some informants are lack information about stunting. Not many people know the term of stunting, even including the stunting family, and they are more familiar with the short term. Furthermore, for the causes of the short toddler, some experts argue that short descendants cause short toddler. The wrong understanding is caused by the lack of awareness of the community towards the development of toddler height. Furthermore, public understanding and concern about nutrition for toddlers are also inadequate; some still believe that the perception of feeding for toddlers is only limited so that the toddler is full, the child does not cry anymore and that the child grows up quickly. Some families do not know much about the quantity and quality of nutritious food.

Based on the results of the research, it shows that the behavior of some mothers towards the practice of exclusive breastfeeding until the age of 6 (six) months of the child is not optimal. Some mothers cannot carry out exclusive breastfeeding for up to 6 (six) months, which is partly due to the relative lack of milk production, and the toddler tends to cry because they are not full. Finally, they are only fed by additional food/milk (formula milk).

Based on the results of interviews with the family of stunting, it is known that the preference of breastfeeding companion given by a part of the family after the age of 6 (six) months is accompanied by promina (complementary food) until the age of 1 (one) year. As for the frequency and amount of food given by families to toddlers, this is still relatively lack due to the family's financial limitations to buy the food. As for other complementary foods such as porridge, their children tend not to like it. So that, toddlers tend to be given Promina porridge because they preferred, and its supply or processing is considered more practical. In terms of the developmental needs of toddler-aged 8 or 9 months, it should have been given porridge. Furthermore, from several cases where mothers work outside the home, supplementary 
feeding is conducted by grandmothers or relatives on the family's side. Parenting is mostly conducted by grandmothers/siblings from the family of the mother or father.

Foods that are usually provided by families for toddlers whose mothers work outside the home tend to be practical or instant foods such as instant noodles and fried foods. In this case, the informant stated that due to the limited financial condition of the family, he had to work, and the provision of varied food for the needs of his toddler children could not be properly fulfilled, so the weight was less than expected (health standards).

Some stunting families have a livelihood in agriculture, such as farmers and farm laborers, working in plantations/gardeners, and trading/stalls. The average income of stunting families interviewed per month ranges from Rp. 800,000 to Rp. 2,000,000. The need of the family depends on the number of family members, and the average number of family members is between 5-7 people. From several stunting cases, it is known that the socio-economic condition of the family is relatively inadequate, so they tend to have limited access to food. Through the condition of economic limitations, some families with stunting cases have limited ability to get access to food, both quantity, and quality. Although they go shopping on the market day once a week, food supplemented with side dishes cannot be provided every day, and the amount is also limited because the number of family members is also relatively large.

Based on the results of interviews and observations, the availability of clean water from stunting families for drinking and cooking needs is inadequate. In this case, families who have access to quality drinking water are still limited. The source of clean water comes from wells without rings found outside the house with an opened-condition. The availability of family toilets in some families does not have a healthy latrine. Some families defecate outside of the house, i.e., in the hole behind the house without a cover. Furthermore, some families are by throwing garbage into the garden (back of the house) without any container. In addition to the condition of the house building, some stunting families do not yet have lighting and ventilation that meet health requirements.

The working area of Parit Public Health Center is relatively broad, covering one village with 28 Jorong and four remote areas. By the condition, the health officers (one nutritionist) becomes one of the obstacles for officers to carry out health promotion and community empowerment about improving community nutrition and prevention of malnutrition and stunting or short. The limited and ineffective health promotion can have an impact on the limited knowledge, attitudes, and behavior of the community towards health care and access to the utilization of health services.

Some stunting families have utilized health workers and health facilities such as Village Maternity Hospital, Nagari Health Post (Poskesri) for health care of pregnant women, childbirth, and toddler health. Furthermore, the community has also used the Integrated Health Post (Posyandu) once a month for activities such as weighing or monitoring weight and height for toddlers, immunization, provision of vitamins, and supplementary feeding (PMT) for toddlers. However, there is still the perception of some people that children under the age of 40 days must not be taken outside of the home, so that toddler health care such as immunization is constrained. It also happens for toddler weighing activities, there are still some mothers of toddlers who do not do a routine weighing by the reasons such as family need, or the child is sick. Consequently, the monitoring of child growth and development, especially for children under three years, cannot be carried out optimally.

The result shows that the attitude and response of some families who have not been positive when the child is sick. In this case, the informant still has the perception that when the child experiences heat because of magic, so when the sick or heat come, they tend to take the child to get help from the shaman. The local community still belive in the shaman medication. 
Some people still believe that non-medical factors cause health problems. Furthermore, when the child's condition becomes worse, they sent the child to see the midwives.

In some cases, when the child needs intensive care and sends to the hospital, the family has difficulties accessing health service. Among the problems include no health insurance, less financial support, and the long location of the Health Care Centers, which is far from their home. Hence, it prevents patients from getting immediate health treatment. This, of course, will have an impact on children's physical growth and development, as well as a high possibility of getting risk becoming stunting.

\section{Discussion}

The following will discuss the aspects causing the incidence of stunting in toddlers, especially from the socio-cultural aspects, economic and environmental conditions, health services, and access to health services.

\subsection{Socio-Cultural Aspects}

The results shows that there are several things considered into causing stunting incident in toddlers in Parit Public Health Center, including those related to parenting and feeding behavior. Parenting and feeding behavior for a toddler is also inseparable from how people's knowledge or perceptions towards stunting and community care to meet the nutritional needs and adequacy for the toddler. The term "stunting" itself is unfamiliar to many people, including the family with stunt children. Mostly they use the term "short". Some families do not know much about the quantity and quality of nutritious food. The limited knowledge of the community about stunting and balanced nutrition for a toddler is due to the ow educational background of the family. The limited number of Public Health Care staff could also become the cause of this situation. Moreover, most of the Public Health Care staff work in hospitals away from the village. Aramico's (2013) shows that low maternal education is at greater risk for stunting (34.4\%), compared to high maternal education (11,\%)[7].

Liem conducted a study in Tangerang Regency in 2018 and found that the term of stunting. The term of stunting, according to the community, is shorter than other children. Delivering various advertisements for stunting can be used as an educational tool and health promotion. Submission of complete information about stunting, its causes, and impacts can correct erroneous perceptions about short toddlers and give awareness to mothers to pay more attention to risk factors and do not neglect the monitoring of children's height [8].

The mother's knowledge about nutrition will determine the mother's behavior and concern in providing food for her toddler. Mothers with good knowledge about nutrition can provide proper support to the growth and development of their toddlers. The result also indicates that some mothers have not provided breastmilk for up to six months. It is in line with this exclusive non-optimal breastfeeding, the results of research by Al Rahmad (2013) in Banda Aceh also reveals that respondents who do not exclusively breastfeed more (75\%) of their toddlers, the toddlers were stunted compared to the normal nutritional status of the toddler. In contrast, respondents who give exclusive breastfeeding, the proportion of toddlers experiencing for stunting is less than $25 \%$ when compared to the normal nutritional conditions of toddlers [9]. The low exclusive breastfeeding is one of the triggers for shortening (stunting) of the toddler in Banda Aceh, which is caused by the past incident that can have an impact on the toddler in the future. Furthermore, Niga's research (2016)[10] also revealed that 
the practice of feeding has a significant relationship to the incidence of stunting. In this case, there is a relationship between exclusive breastfeeding and the incidence of stunting in the toddler. Exclusive breastfeeding affects the change in stunting status because of the function of exclusive breastfeeding as an anti-infection. The toddler who did not well breastfeed had a high possibility of getting infectious diseases such as diarrhea and respiratory diseases because breast milk is an anti-infection and can reduce the risk of stunting.

The research shows that many children age six months to 1 (one) year did not get any supplementary. The category of unfavorable parenting risks 8.07 times greater than good parenting, each with a percentage of nutritional status of stunting is $53 \%$ and $12.3 \%$ [7].

Based on the results of the study also revealed that eating patterns and habits in children over one year old tend to be out of the health recommendations. Likewise, the attention and awareness of parents (mothers) towards the needs and nutritional adequacy of children is inadequate. Related to this, the result of Ningrum's research (2019) also reveals that there is still a lack of patience in the provision of various mothers' food for their infants. Most mothers only rely on additional food provided by the Integrated Health Post or buying instant baby food.

\subsection{Socio-Economic and Environmental Conditions}

The condition factor of the relatively low level of community education causes the limitations of the community in getting jobs and adequate income. Some of the stunting families have a livelihood in agriculture, the average income per month ranges from Rp. 800,000 to Rp. 2,000,000, and the average number of family members is between 5-7 people. Umar's research results (2019) states that the number of dependents/family has a positive effect on stunting. If the number of dependents increases by 1 (one) person, then the probability of stunting is $0.7 \%$. Increasing the number of dependents will increase the amount of household need. If the need increases without having a balanced income, there will be problems such as nutritious food intake. It can cause the risk of stunting [11].

The socio-economic condition of the families can affect the family's ability to buy food. Based on the results of the research, it shows that the socio-economic condition of the family is relatively inadequate, so they tend to have limited access to food. This certainly can impact the growth and development of the toddler. The results of Ningrum's research (2019) [12] in Klaten Regency also reveals that in terms of the economic characteristics of parents, the average parent's occupation in toddlers with stunting are laborers, both agricultural laborers and construction workers. The average income of parents per month is Rp1,000,000 to $\mathrm{Rp} 2,000,000$. Through the condition of this limited income, results incomplete of balanced nutrition for toddlers.

Based on the results of the research,it is known that the availability of clean water from stunting families for drinking and cooking needs is inadequate. The source of clean water comes from wells without rings found outside the house with an opened-condition. When it is observed from the source of clean water, the risk for water pollution from feces or animals is quite large. Furthermore, the availability of family toilets where some families do not have a healthy latrine, some families defecate outside of the house, and the handling of rubbish is by throwing garbage into the garden. Such unfavorable family behaviors and habits can pose a risk to the health of toddlers become vulnerable to diseases, especially infectious diseases such as diarrhea and respiratory infections, and ultimately can affect the weight/height and the development of toddler health. Environmental sanitation conditions from families of unhealthy stunting cases can affect the health of toddlers or children vulnerable to infectious diseases such as tuberculosis and diarrhea, which can have an impact on the nutritional status of the 
toddler. The case of stunting is higher in families that do not have toilet facilities and unhealthy drinking water. Infectious diseases, such as diarrhea and ISPA, are affected by environmental factors. The condition of the house which has not met the conditions and water sources as well as the disposal of feces that are not good [10].

\subsection{Health Care and Access to Health Services}

Based on the research results, it is known that some stunting families have utilized health workers and health facilities. However, there is still the perception of some people that children under the age of 40 days must not be taken outside of the home, so that toddler health care such as immunization is constrained. Regarding the immunization, the results of research conducted in India suggest that malnutrition is more common in toddlers who are not immunized than toddlers who are immunized. Immunized children receive protection from several diseases, and this can affect nutritional status [10].

Limited public knowledge about an illness can affect attitudes and responses when dealing with a sick family. Base on the results of the research, it is found that the attitude and response of some families who have not been positive when the child is sick. Some people still believe that a child's body caused by the heat factor is outside of the medics. Furthermore, when the child's condition is severe, then he will be taken to the village midwives. The access to health services and the handling of diseases can have an impact on children's physical growth and development and risk becoming stunting toddlers.

\section{Conclusion}

Several aspects are causing the incidence of stunting in the working area of Parit Public Health Center in Pasaman Barat Regency, namely socio-cultural aspects including parenting and feeding behavior (family knowledge and understanding of balanced stunting and nutrition, parenting patterns and feeding behavior in toddlers). Furthermore, the stunting is also motivated by economic conditions and the family environment, health care, and access to health services.

Alternative suggestions that can be proposed are: 1) increasing public knowledge about stunting and stunting prevention efforts through optimizing socialization efforts, promoting health and communicating behavior change, promoting cross-sector collaboration for integrated collaboration and integration, 2)-implementing behavioral change interventions for stunting prevention by taking into account the strengthening of the environment including efforts to increase family income, understanding and awareness of individuals, families, and communities that affect parenting, consumption patterns, environmental health, health care and access to health services, 3) - optimizing community empowerment through increasing the use of Dasawisma in PKK as a driving force for growth and behavior change monitoring.

\section{Acknowledgement}

The author would like to thank the Department of Research and Development of West Sumatra Province, which has provided the opportunity and support to the authors in carrying out this research. Furthermore, thank you to the Health Department of Solok Regency and staff who have become the research location and all those parties who have assisted in conducting the research. 


\section{References}

[1] Aridiyah FO, Rohmawati N, R. M.: Faktor-faktor yang MempengaruhiKejadian Stunting pada Anak Balita di Wilayah Pedesaan dan Perkotaan. E-Jurnal PustakaKesehatan, 3 (no. 1) (2015)

[2] Badan Penelitian dan Pengembangan Kesehatan.: Laporan Riset Kesehatan Dasar (Jakarta:Balitbangkes). (2013)

[3] Pemerintah Provinsi Sumatera Barat: Peraturan Daerah Provinsi Sumatera Barat Nomor 6 Tahun 2016 tentang Rencana Pembangunan Jangka Menengah (RPJM) Derah Provinsi Sumatera Barat (2016-2021). (2016)

[4] Dinas Kesehatan.: Laporan Tahunan Kesehatan Keluarga. Padang (2018).

[5] Dinas Kesehatan.: Laporan Tahunan Kesehatan Keluarga (Simpang Ampek: Dinas Kesehatan Pasaman Barat). Kabupaten Pasaman Barat (2018)

[6] Permampu, K.: Laporan Penelitian Persoalan dan Pemenuhan Gizi Perempuan dan Perempuan Muda 8 Provinsi di Sumatera Barat. (2017)

[7] Aramico Basri, SudargoT, S. J.: Hubungan sosial ekonomi, pola asuh, polamakan dengan stunting pada siswa sekolah dasar di Kecamatan Lut Tawar, Kabupaten Aceh Tengah. Jurnal Gizi danDieletik Indonesia, Vol. 1, No, 121-130. (2013)

[8] Liem, S., Panggabean, H., \& Farady, R.: Persepsi Sosial Tentang Stunting Di Kabupaten Tangerang Social Perception on Stunting in Tangerang District, 37-47. (2019)

[9] Al-Rahmad AH, Miko A, H. A. (2013). Kajian Stunting Pada Anak Balita Ditinjau Dari Pemberian ASI Ekslusif, MP-ASI, Status Imunisasi Dan Karakteristik Keluarga di Kota Banda Aceh. Jurnal Kesehatan Ilmiah Nasuwakes, Vol.6 No.2, 169 - 184.

[10] Niga DM, P. W.: Hubungan Antara Praktik Pemberian Makan, Perawatan Kesehatan, dan Kebersihan Anak Dengan Kejadian Stunting Pada AnakUsia 1-2 Tahun di Wilayah Kerja Puskesmas Oebodo Kota Kupang. Jurnal Wiyata, Vol. 3 No. (2016)

[11] Umar, H. T.: Kondisi Sosial Ekonomi RumahTangga dan Masalah Stunting Balita di Indonesia. Media Trend Berkala Kajian Ekonomi Dan Studi Pembangunan, 14 (1), 41-48. (2019)

[12] NingrumV.: Akses Pangan dan Kejadian Balita Stunting: Kasus Pedesaan Pertanian di Klaten. Jurnal Pangan, Vol.28, Nol 2019.(2019) 